\title{
Species Distribution Models and Ecological Suitability Analysis for Potential Tick Vectors of Lyme Disease in Mexico
}

\author{
Patricia Illoldi-Rangel, ${ }^{1}$ Chissa-Louise Rivaldi, ${ }^{1}$ Blake Sissel, ${ }^{1}$ Rebecca Trout Fryxell, ${ }^{2}$ \\ Guadalupe Gordillo-Pérez, ${ }^{3}$ Angel Rodríguez-Moreno, ${ }^{4}$ Phillip Williamson, ${ }^{5}$ \\ Griselda Montiel-Parra, ${ }^{6}$ Víctor Sánchez-Cordero, ${ }^{4}$ and Sahotra Sarkar ${ }^{1}$
}

${ }^{1}$ Section of Integrative Biology, University of Texas at Austin, Austin, TX 78712, USA

${ }^{2}$ Department of Pathology, Microbiology and Immunology, School of Veterinary Medicine, University of California Davis, Davis, CA 95616, USA

${ }^{3}$ Centro Médico Nacional SXXI, Unidad de Investigación Médica de Enfermedades Infecciosas y Parasitarias, IMSS, Avenida Cuauhtémoc 330, Colonia Doctores 06725 México, DF, Mexico

${ }^{4}$ Laboratorio de Sistemas de Información Geográfica, Departamento de Zoología, Instituto de Biología, UNAM, Circuito Exterior, Apartado Postal 70-153, Coyoacán, 04510 México, DF, Mexico

${ }^{5}$ Department of Forensic and Investigative Genetics, University of North Texas Health Science Center, 3500 Camp Bowie Boulevard, Fort Worth, TX 76107, USA

${ }^{6}$ Colección Nacional de Ácaros, Departamento de Zoología, Instituto de Biología, UNAM, Circuito Exterior, Apartado Postal 70-153, Coyoacán, 04510 México, DF, Mexico

Correspondence should be addressed to Sahotra Sarkar, sarkar@mail.utexas.edu

Received 15 July 2011; Accepted 23 October 2011

Academic Editor: Nildimar Honório

Copyright ( $) 2012$ Patricia Illoldi-Rangel et al. This is an open access article distributed under the Creative Commons Attribution License, which permits unrestricted use, distribution, and reproduction in any medium, provided the original work is properly cited.

\begin{abstract}
Species distribution models were constructed for ten Ixodes species and Amblyomma cajennense for a region including Mexico and Texas. The model was based on a maximum entropy algorithm that used environmental layers to predict the relative probability of presence for each taxon. For Mexico, species geographic ranges were predicted by restricting the models to cells which have a higher probability than the lowest probability of the cells in which a presence record was located. There was spatial nonconcordance between the distributions of Amblyomma cajennense and the Ixodes group with the former restricted to lowlands and mainly the eastern coast of Mexico and the latter to montane regions with lower temperature. The risk of Lyme disease is, therefore, mainly present in the highlands where some Ixodes species are known vectors; if Amblyomma cajennense turns out to be a competent vector, the area of risk also extends to the lowlands and the east coast.
\end{abstract}

\section{Introduction}

Lyme disease, the most frequently reported tick-borne infectious disease in the United States and Europe $[1,2]$, is increasingly being reported from Mexico [3, 4], where disease cases are more prevalent during warm-weather months when ticks are active. The etiologic agent, Borrelia burgdorferi, enters the skin at the site of the tick bite; after incubating for 3-30 days, the bacteria migrate through the skin and may spread to lymph nodes or disseminate through the bloodstream to other parts of the body. While B. burgdorferi infection might be endemic in Mexico $[3,4]$ it is relatively rare in the southern USA making the question of its biogeography a matter of interest.

Additionally, in Mexico, the epidemiology and biogeography of Lyme disease are not well understood [5]. Several tick species have recently been identified as containing $B$. burgdorferi using a DNA polymerase chain reaction and, therefore, may be considered as candidates that may be involved in the enzootic transmission cycle in both Mexico and South America. These include tick species from the genus Ixodes [3,4] as well as Amblyomma cajennense [5, David Beck, personal communication]. While detection of B. burgdorferi DNA by polymerase chain reaction is not 
indicative of vector competence, the presence of B. burgdorferi in the molecular surveys does indicate a benefit from modeling the distribution of $A$. cajennense since it has been shown to feed on reservoirs for B. burgdorferi in Mexico. Additionally, the South American A. cajennense has been shown to be a competent vector for Rickettsia rickettsii [6], the causative agent of Rocky Mountain spotted fever, and has been shown to carry additional Rickettsia species which belong to the spotted fever group [7].

Ixodes ticks are hematophagous parasites during all active life stages. They have great importance from economic, veterinary, and human health vantage perspectives because of their capacity to transmit a variety of diseases to humans and animals [8]. These species are parasites of birds or mammals. In Mexico, 26 Ixodes species have been identified; these were collected from 20 of Mexico 32 states [9]. The distribution of A. cajennense extends from the southern regions of the United States (Texas) to the Caribbean Islands, and across Central and South America to northern Argentina, excluding the mountain regions $[10,11]$. As a consequence, if $A$. cajennense was to contribute to maintenance of $B$. burgdorferi in the zoonotic cycle in any way or be a competent vector for a variety of spotted fevers in Mexico, the health impact could be significant. Thus far, A. cajennense has not been found north of latitude $27^{\circ} \mathrm{N}$ or south of latitude $29^{\circ} \mathrm{S}$ and its geographic range may be limited by temperature [10]. Low temperatures in mountainous areas such as the Mexican Sierra Madre and the Andes may be an obstacle for its establishment. With this restriction, the species is known to survive in regions with very different ecological conditions, spanning from arid grasslands to tropical forests [10].

The purpose of this paper is to explore the biogeography of Ixodes ticks and A. cajennense in Mexico and the suitability of different ecoregions and habitat types to their potential establishment using species distribution models (SDMs). This technique has been systematically developed to explore vector-borne zoonotic disease ecology and biogeography during the last 15 years $[12,13]$, and several studies have applied it to Mexico and nearby regions [14-16]. The goal was to determine the ecological variables that best predict georeferenced distributional data of a species collected through fieldwork, from museum collections, and so forth. These predictive variables are interpreted as identifying the potential geographical distribution of a species [17] and are sometimes also interpreted as identifying its fundamental niche $[14,18-20]$. When biogeographic, behavioral, and other limitations to dispersal are taken into account, the potential distribution is refined to a predicted (realized) distribution.

For species that are relevant to the transmission of a disease, the relative suitability of different regions within the predicted distribution, as measured on a continuous scale, establishes the relative spatial ecological risk $[13,16,17]$. For vector-borne zoonotic diseases, a composite measure for this risk must include the SDMs of all relevant vector and reservoir species. This risk can then be combined with other measures of risk, including socioeconomic factors and disease case prevalence. A variety of techniques have been developed to carry out such increasingly sophisticated disease risk analyses [17].

Because of a lack of data on other factors, this study is restricted to SDMs for potential tick vectors of Lyme disease. The aim was to analyze the predicted biogeography and habitat suitability for the Ixodes species, treated jointly, and A. cajennense. Ixodes species seem to be the most likely candidates for the transmission of Lyme disease in Mexico, and A. cajennense has been shown to be a competent vector for multiple tick-borne rickettsioses. Besides establishing the relative risk of the transmission of these diseases from these taxa, these SDMs will also permit prediction of the distributions of potentially epidemiologically relevant vector and reservoir distributions. This will allow the identification of the most likely candidates to transmit $B$. burgdorferi infections so that future studies can be guided by a better theoretical understanding of the underlying ecology of Lyme disease in Mexico.

A wide variety of techniques exist for SDM construction [21]. If presence-only (rather than presence-absence) data are all that are available, as is typically the case (including this study), machine-learning algorithms provide the most reliable results $[21,22]$. These use georeferenced data on species occurrence points and environmental layers as input variables; as output they either provide binary predictions of presence or absence or a continuous measure than can be interpreted as relative habitat suitability. For risk analysis the latter is preferable. For this study, we chose a maximum entropy algorithm implemented in the MaxEnt software package [23-25] because, besides providing continuous output, its performance has been established as being as good or better than available alternatives [21,22]. This choice has also become standard in constructing SDMs for systematic conservation planning [26-28].

\section{Materials and Methods}

\subsection{Data}

2.1.1. Tick Occurrence Data. Tick occurrence data were compiled from various sources including new field collections and information from prior publications. The field data were obtained from the University of North Texas Health Science Center, The University of Texas at Austin, the Texas Department of State Health Services (TX DSHS) and the Instituto de Biología, UNAM, Mexico. Specimens were identified by morphologic examination and by PCR amplification of $12 \mathrm{~S}$ rDNA followed by sequence determination of the amplification products using the method of Williamson et al. [29]. All points were georeferenced using the MaNIS protocol (http://manisnet.org/GeorefGuide.html, last accessed 19 June 2011). Additional data came from Dergousoff et al. [30].

SDMs were constructed for an area including Mexico and Texas, both of which had sparse occurrence records; there were insufficient data to construct reliable models for Mexico or Texas alone. Table 1 lists all the data that were available for all species in Mexico and Texas and is restricted to those used in this analysis, along with the number of points that satisfied the error constraint (see Section 2.2) and the number of such 
TABLE 1: Total number of records and final number of records used to generate the analysis.

\begin{tabular}{|c|c|c|c|c|c|c|}
\hline \multirow{2}{*}{ Tick species } & \multicolumn{3}{|c|}{ Mexico } & \multicolumn{3}{|c|}{ Texas } \\
\hline & Total number & $\begin{array}{l}\text { Number with } \\
\text { adequate precision }\end{array}$ & $\begin{array}{l}\text { Independent } \\
\text { cells }\end{array}$ & Total number & $\begin{array}{l}\text { Number with } \\
\text { adequate precision }\end{array}$ & $\begin{array}{l}\text { Independent } \\
\text { cells }\end{array}$ \\
\hline Amblyomma cajennense & 10 & 10 & 9 & 269 & 269 & 69 \\
\hline Ixodes boliviensis & 10 & 1 & 1 & 0 & 0 & 0 \\
\hline Ixodes conepati & 2 & 2 & 2 & 0 & 0 & 0 \\
\hline Ixodes cookei & 3 & 3 & 3 & 0 & 0 & 0 \\
\hline Ixodes eadsi & 5 & 4 & 4 & 0 & 0 & 0 \\
\hline Ixodes kingi & 1 & 1 & 1 & 0 & 0 & 0 \\
\hline Ixodes marxi & 1 & 1 & 1 & 0 & 0 & 0 \\
\hline Ixodes scapularis & 5 & 4 & 3 & 56 & 56 & 51 \\
\hline Ixodes sculptus & 0 & 0 & 0 & 1 & 1 & 1 \\
\hline Ixodes texanus & 2 & 1 & 1 & 0 & 0 & 0 \\
\hline
\end{tabular}

TABLE 2: Environmental parameters for species distribution models.

Parameters
Annual mean temperature
Mean diurnal range
Isothermality
Temperature seasonality
Maximum temperature of warmest month
Minimum temperature of coldest month
Temperature annual range
Mean temperature of the wettest quarter
Mean temperature of the driest quarter
Mean temperature of the warmest quarter
Mean temperature of the coldest quarter annual precipitation
Precipitation of wettest month
Precipitation of driest month
Precipitation seasonality
Precipitation of wettest quarter
Precipitation of driest quarter
Precipitation of warmest quarter
Precipitation of coldest quarter
Elevation
Slope
Aspect
Compound topographic index

points in independent cells. All data have been submitted to the Disease Vectors Database [31]. Given that the area of epidemiological interest for this paper was Mexico, the model results that were subjected to further analysis and are presented here are for Mexico.

2.1.2. Environmental Layers. The environmental layers used are listed in Table 2. These include four topographical variables (elevation, slope, aspect, and compound topographical index) and 19 bioclimatic variables. The latter were obtained from the WorldClim database [32] (http:// www.worldclim.org/; last accessed 28 February 2010). Elevation data were obtained from the United States Geological Survey Hydro-1K DEM data set (http://eros.usgs .gov/\#/Find_Data/Products_and_Data_Available/gtopo30/hydro; last accessed 28 February 2010). Slope, aspect, and the compound topographical index were derived from the DEM using the Spatial Analyst extension of ArcMap 9.3.

2.2. Species Distribution Models. The study area of Mexico and Texas was divided into 3429052 cells at a resolution of 30 arcseconds. The average cell area was $0.77 \mathrm{~km}^{2}$. Data were retained for this analysis only if the estimated error was less than 1 arcminute. Data prior to 1990 was excluded from the present analysis. Table 2 shows the number of data that were retained. A conservative threshold of independent data points (i.e., those falling in different cells at the resolution of this analysis) was used for model construction, namely, at least 10 independent cells [17].

SDMs were constructed separately for A. cajennense, but for together 10 Ixodes species (I. boliviensis, I. conepati, I. cookie, I. eadsi, I. kingi, I. marxi, I. scapularis, I. sculptus, and I. texanus) for three reasons: (i) though from this group only I. scapularis has so far been implicated as a vector for Lyme disease, other Ixodes species (e.g., I. pacificus and those of the I. ricinus complex) are also confirmed vectors. Consequently, it remains possible that these others may be competent vectors. (ii) The provenance of data points suggested that several of these species often cooccur (e.g., I. scapularis and I. sculptus in Texas). Given the sparse data points available, this meant that the geographical range of these potential vectors may be significantly underestimated if the SDMs were constructed separately for each species. (iii) Treating the data points together allowed much more reliable SDM construction because of the higher number of data points available for input.

Following a standard protocol [17], MaxEnt (Ver. 3.3.4) was run with the threshold and hinge features and without duplicates so that there was at most one sample per pixel; linear, quadratic, and product features were used. The convergence threshold was set to a conservative $1.0 \times 10^{-5}$. For the AUC, that is, the area under the receiver-operating characteristic (ROC) curve, averages over 100 replicate models were computed. For each model the test: training ratio was set to 40:60 following Phillips and Dudik [25] which means that models were constructed using $60 \%$ of the data and tested with the remaining $40 \%$. An acceptability threshold of 0.90 was used for both the test and training AUCs, well above the standard 0.60 used in the literature. 
TABLE 3: Size (area) of predicted range of Amblyomma cajennense and the Ixodes group.

\begin{tabular}{|c|c|c|c|c|}
\hline \multirow{2}{*}{ State } & \multicolumn{2}{|c|}{ Amblyomma cajennense } & \multicolumn{2}{|c|}{ Ixodes } \\
\hline & No. cells & Area $\left(\mathrm{km}^{2}\right)$ & No. cells & Area $\left(\mathrm{km}^{2}\right)$ \\
\hline Aguascalientes & 0 & 0 & 1226 & 944.02 \\
\hline Baja California & 1995 & 1536.15 & 3081 & 2372.37 \\
\hline Baja California Sur & 2467 & 1899.59 & 1230 & 947.1 \\
\hline Campeche & 21243 & 16357.11 & 7602 & 5853.54 \\
\hline Chiapas & 2238 & 1723.26 & 17743 & 13662.11 \\
\hline Chihuahua & 70 & 53.9 & 2380 & 1832.6 \\
\hline Coahuila & 11578 & 8915.06 & 41080 & 31631.6 \\
\hline Colima & 114 & 87.78 & 152 & 117.04 \\
\hline Distrito Federal & 0 & 0 & 785 & 604.45 \\
\hline Durango & 986 & 759.22 & 37042 & 28522.34 \\
\hline Estado de Mexico & 8 & 6.16 & 18010 & 13867.7 \\
\hline Guanajuato & 654 & 503.58 & 20401 & 15708.77 \\
\hline Guerrero & 37 & 28.49 & 4747 & 3655.19 \\
\hline Hidalgo & 997 & 767.69 & 19004 & 14633.08 \\
\hline Jalisco & 542 & 417.34 & 20600 & 15862 \\
\hline Michoacán & 39 & 30.03 & 22676 & 17460.52 \\
\hline Morelos & 0 & 0 & 490 & 377.3 \\
\hline Nayarit & 6087 & 4686.99 & 3415 & 2629.55 \\
\hline Nuevo León & 43863 & 33774.51 & 42073 & 32396.21 \\
\hline Oaxaca & 11002 & 8471.54 & 32519 & 25039.63 \\
\hline Puebla & 2594 & 1997.38 & 18786 & 14465.22 \\
\hline Querétaro & 204 & 157.08 & 10271 & 7908.67 \\
\hline Quintana Roo & 6338 & 4880.26 & 1307 & 1006.39 \\
\hline San Luis Potosí & 13836 & 10653.72 & 17477 & 13457.29 \\
\hline Sinaloa & 2683 & 2065.91 & 3716 & 2861.32 \\
\hline Sonora & 1409 & 1084.93 & 12211 & 9402.47 \\
\hline Tabasco & 7571 & 5829.67 & 147 & 113.19 \\
\hline Tamaulipas & 80607 & 62067.39 & 29230 & 22507.1 \\
\hline Tlaxcala & 0 & 0 & 4571 & 3519.67 \\
\hline Veracruz & 63260 & 48710.2 & 14420 & 11103.4 \\
\hline Yucatán & 7966 & 6133.82 & 99 & 76.23 \\
\hline Zacatecas & 4 & 3.08 & 17027 & 13110.79 \\
\hline
\end{tabular}

Obtaining predicted ranges for the sake of comparisons required the conversion of SDM outputs, which were relative probabilities (specifying habitat suitability) into binary predictions of presence or absence. This was done using a threshold of 0.10 for A. cajennense and 0.12 for the Ixodes group which corresponded to the lowest probability predicted by the SDMs for an occurrence point used in model construction. The threshold was used after normalization of the MaxEnt output in Mexico so that the highest predicted value for occurrence in each model was 1 for at least one cell in the landscape.

\section{Results and Discussion}

3.1. Species Distribution Models. Figure 1 presents the species distribution model for $A$. cajennense Figure 2 and that for the present Ixodes group. For the 100 replicate models, for $A$. cajennense, the average test AUC was 0.91, the training was 0.99; for the Ixodes group, the corresponding numbers were 0.93 and 0.98 . Figure 3 presents both distributions together showing their almost complete nonconcordance, which we will refer to as their "complementarity."
Table 3 presents the areas occupied by the predicted distributions for the states of Mexico (see, also, Figures 4 and 5). The Ixodes group is predicted to be present in all states, while A. cajennense is predicted for all of them except Aguascalientes, Distrito Federal (Mexico City), Morelos, and Tlaxcala, all of which are located in central Mexico. The main distribution predicted for A. cajennense is in Veracruz $(21.8 \%)$ and Tamaulipas $(27.8 \%)$ (Figure 4$)$, both in the northeast coast of Mexico and both having lowlands and warm temperatures [32]. In contrast, the Ixodes group is predicted mainly in Durango (8.7\%), Coahuila (9.6\%), Nuevo León (9.9\%) (Figure 5), and all of the northern states characterized by the presence of high altitudes and temperate vegetation (see below).

3.2. Ecological Suitability. Table 4 presents the altitudinal dependence of the two SDMs. Although the complete predicted $A$. cajennense range is between 0 and $2800 \mathrm{~m}$, most of it (95\%) occurs between 200 and $1000 \mathrm{~m}$. This result agrees with Solís [33] who found this species only in areas with altitudes below $1000 \mathrm{~m}$ even though, geographically, the species is widely distributed in the warmer parts of Latin 
TABLE 4: Altitudinal intervals and predicted ranges of Amblyomma cajennense and the Ixodes group.

\begin{tabular}{|c|c|c|c|c|}
\hline \multirow{2}{*}{ Interval } & \multicolumn{2}{|c|}{ Amblyomma cajennense } & \multicolumn{2}{|c|}{ Ixodes } \\
\hline & No. cells & Area $\left(\mathrm{km}^{2}\right)$ & No. cells & Area $\left(\mathrm{km}^{2}\right)$ \\
\hline $1-200$ & 148 & 113.96 & 0 & 0 \\
\hline $201-400$ & 13833 & 10651.41 & 5382 & 4144.14 \\
\hline $401-600$ & 6189 & 4765.53 & 16702 & 12860.54 \\
\hline $601-800$ & 3296 & 2537.92 & 16647 & 12818.19 \\
\hline $801-1000$ & 1351 & 1040.27 & 13644 & 10505.88 \\
\hline $1001-1200$ & 476 & 366.52 & 12412 & 9557.24 \\
\hline $1201-1400$ & 145 & 111.65 & 13443 & 10351.11 \\
\hline $1401-1600$ & 106 & 81.62 & 15187 & 11693.99 \\
\hline $1601-1800$ & 86 & 66.22 & 17187 & 13233.99 \\
\hline $1801-2000$ & 131 & 100.87 & 17490 & 13467.3 \\
\hline $2001-2200$ & 92 & 70.84 & 22017 & 16953.09 \\
\hline $2201-2400$ & 38 & 29.26 & 26877 & 20695.29 \\
\hline $2401-2600$ & 65 & 50.05 & 26918 & 20726.86 \\
\hline $2601-2800$ & 56 & 43.12 & 19741 & 15200.57 \\
\hline $2801-3000$ & 8 & 6.16 & 8194 & 6309.38 \\
\hline $3001-3200$ & 0 & 0 & 3201 & 2464.77 \\
\hline $3201-3400$ & 0 & 0 & 1449 & 1115.73 \\
\hline $3401-3600$ & 0 & 0 & 761 & 585.97 \\
\hline $3601-3800$ & 0 & 0 & 450 & 346.5 \\
\hline $3801-4000$ & 0 & 0 & 234 & 180.18 \\
\hline $4001-4200$ & 0 & 0 & 108 & 83.16 \\
\hline $4201-4400$ & 0 & 0 & 59 & 45.43 \\
\hline $4401-4600$ & 0 & 0 & 18 & 13.86 \\
\hline $4601-4800$ & 0 & 0 & 8 & 6.16 \\
\hline $4801-5000$ & 0 & 0 & 3 & 2.31 \\
\hline$>5000$ & 0 & 0 & 1 & 0.77 \\
\hline
\end{tabular}

TABLE 5: Ecoregion occupancy by Amblyomma cajennense and the Ixodes group.

\begin{tabular}{|c|c|c|c|c|}
\hline \multirow{2}{*}{ Ecoregion } & \multicolumn{2}{|c|}{ Amblyomma cajennense } & \multicolumn{2}{|c|}{ Ixodes } \\
\hline & No. cells & Area $\left(\mathrm{km}^{2}\right)$ & No. cells & Area $\left(\mathrm{km}^{2}\right)$ \\
\hline Pine and oak forest & 3112 & 2396.24 & 196510 & 151312.7 \\
\hline Cloud forest & 179 & 137.83 & 8913 & 6863.01 \\
\hline Chaparral & 1681 & 1294.37 & 777 & 598.29 \\
\hline Mangrove & 10432 & 8032.64 & 0 & 0 \\
\hline Tamaulipan scrub thorn forest & 84540 & 65095.8 & 46848 & 36072.96 \\
\hline Submontane scrubland & 22664 & 17451.28 & 24305 & 18714.85 \\
\hline Xeric scrubland & 9409 & 7244.93 & 74934 & 57699.18 \\
\hline Marshes of Centla & 1135 & 873.95 & 0 & 0 \\
\hline Tropical rainforest & 110791 & 85309.07 & 31043 & 23903.11 \\
\hline Tropical deciduous forest & 46377 & 35710.29 & 42190 & 32486.3 \\
\hline Tropical dry forest & 799 & 615.23 & 0 & 0 \\
\hline
\end{tabular}

America and the Caribbean [33]. However, in Guatemala, an ecological and epidemiological study of ticks [34] recorded that the presence of $A$. cajennense occurs up to $1400 \mathrm{~m}$ in areas with a marked rainy season (six months of rain and six months for dry season) [35]. The SDMs predict an expanded altitudinal range while confirming that the best habitat is between 200 and $1000 \mathrm{~m}$.

For the Ixodes group (Table 4), the complete altitudinal range goes from $200 \mathrm{~m}$ to over $5000 \mathrm{~m}$ though most of it $(98 \%)$ is restricted to below $3600 \mathrm{~m}$. The altitudinal range of the Ixodes group thus also complements that of A. cajennense, partly accounting for the geographical complementarity noted earlier.

Table 5 shows the ecoregional distribution of the two SDMs (see, also, Figures 6 and 7). Although both SDMs share ecoregions, A. cajennense presence was primarily predicted for ecoregions such as mangroves and marshes along the coast of Mexico at low altitudes (Figure 6). In Mexico and the United States, this species is found in areas where the mean temperature is around $13^{\circ}-16^{\circ} \mathrm{C}$ and the NDVI is high [36]. Relatively low mean temperatures and differences in the seasonal patterns of rainfall may limit this species 
TABLE 6: Vegetation types for Amblyomma cajennense and the Ixodes group.

\begin{tabular}{|c|c|c|c|c|}
\hline \multirow{2}{*}{ Vegetation type } & \multicolumn{2}{|c|}{ Amblyomma cajennense } & \multicolumn{2}{|c|}{ Ixodes } \\
\hline & No. cells & Area $\left(\mathrm{km}^{2}\right)$ & No. cells & Area $\left(\mathrm{km}^{2}\right)$ \\
\hline Grassland & 925 & 712.25 & 6602 & 5083.54 \\
\hline Scrubland & 9560 & 7361.2 & 14920 & 11488.4 \\
\hline Pine forest & 72 & 55.44 & 6478 & 4988.06 \\
\hline Oak forest & 392 & 301.84 & 7602 & 5853.54 \\
\hline Pine-oak forest & 76 & 58.52 & 9654 & 7433.58 \\
\hline Tropical rainforest & 4116 & 3169.32 & 2622 & 2018.94 \\
\hline Tropical deciduous forest & 4815 & 3707.55 & 6541 & 5036.57 \\
\hline Aquatic inland vegetation & 1330 & 1024.1 & 14 & 10.78 \\
\hline Cloud forest & 14 & 10.78 & 1501 & 1155.77 \\
\hline Mangle & 473 & 364.21 & 0 & 0 \\
\hline Palms/palm plantations & 30 & 23.1 & 18 & 13.86 \\
\hline Savanna & 195 & 150.15 & 48 & 36.96 \\
\hline Other vegetation types/not known & 28921 & 22269.17 & 17818 & 13719.86 \\
\hline
\end{tabular}

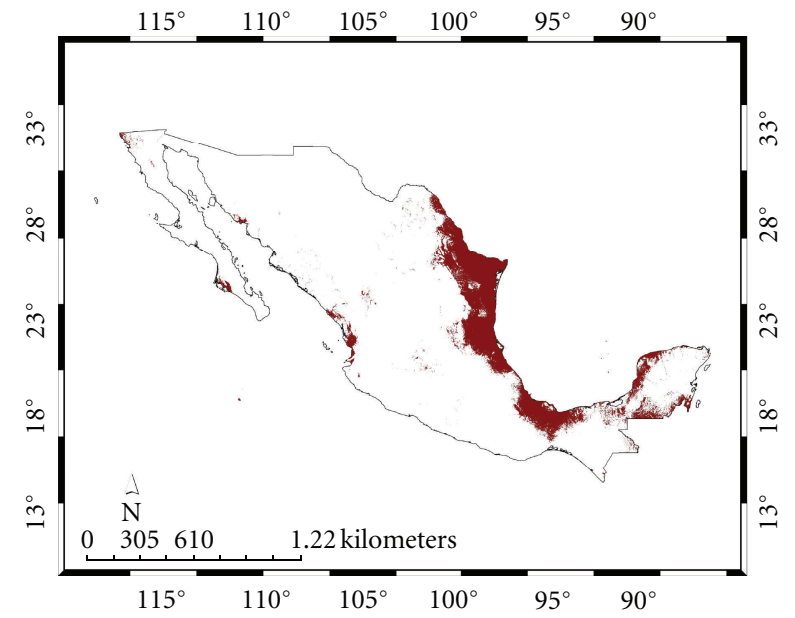

Figure 1: Species distribution model for Amblyomma cajennense.

colonization of areas to the north of its current distribution. Low temperatures are likely keeping the species out of elevated areas, such as the Sierra Madre in Mexico. The southern distribution of $A$. cajennense appears to be mainly restricted by relatively low temperatures and not by low humidity [36].

Table 6 shows the different vegetation types associated with both models (see, also, Figures 8 and 9). Although both SDMs share scrubland as the main vegetation type, 18.7 and $20.0 \%$, respectively, for A. cajennense and the Ixodes group, the former is mainly associated with tropical deciduous and rainforest $(17.4 \%)$, while the latter is associated with oak and pine-oak forest $(23.3 \%)$. These predictions agree with Álvarez et al. [35] who collected A. cajennense in tropical wet forests and its transitions. It is likely that suitable $A$. cajennense habitat consists of warmer areas with moderate precipitation.

Moreover, suitable A. cajennense habitat is predicted to be restricted to areas with more dense or mixed vegetation and tall grass [37]. A study of horse farms showed that pastures

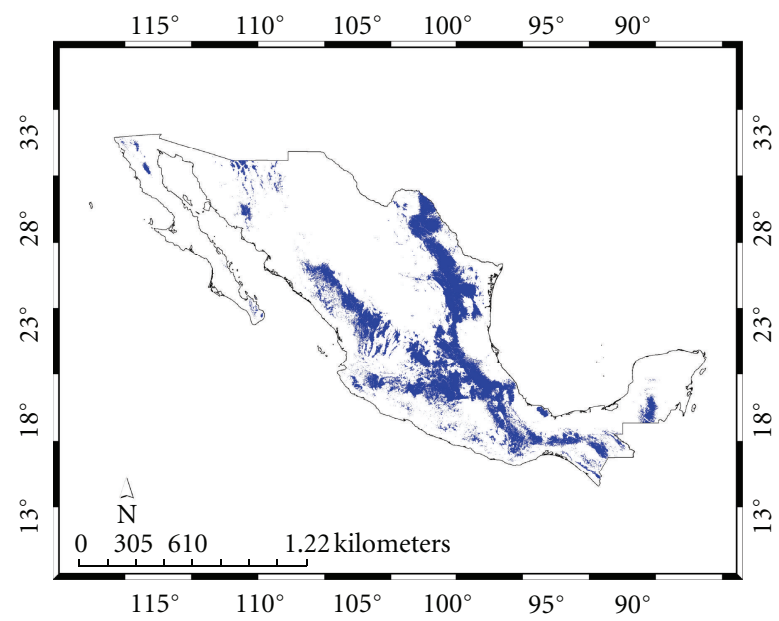

FIgURE 2: Species distribution model for the Ixodes group.

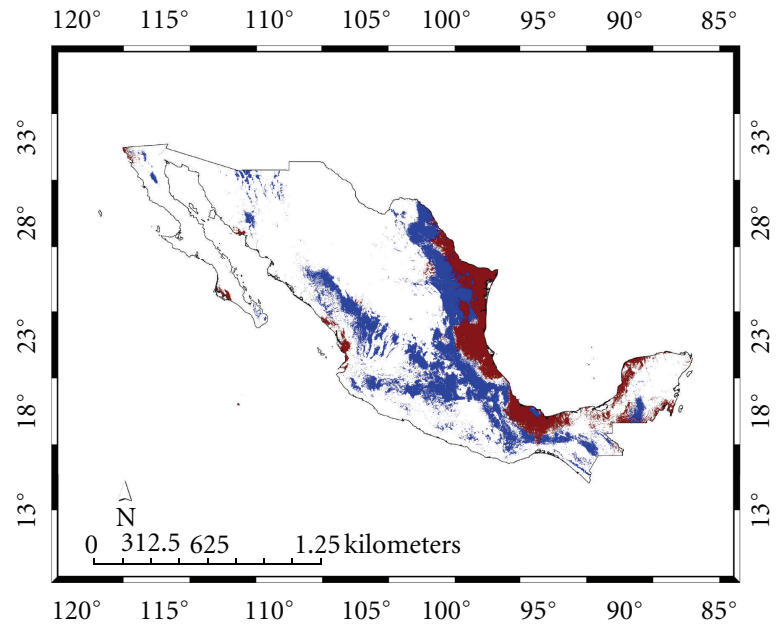

FIGURE 3: Complementarity of models for Amblyomma cajennense and the Ixodes group. 


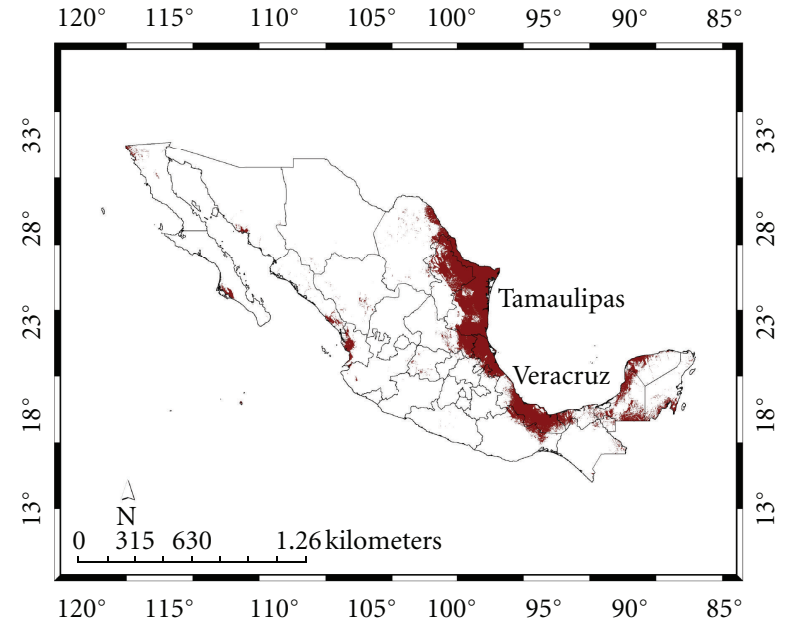

Figure 4: Species distribution model and Mexican states for Amblyomma cajennense. The principal states are shown (see text).

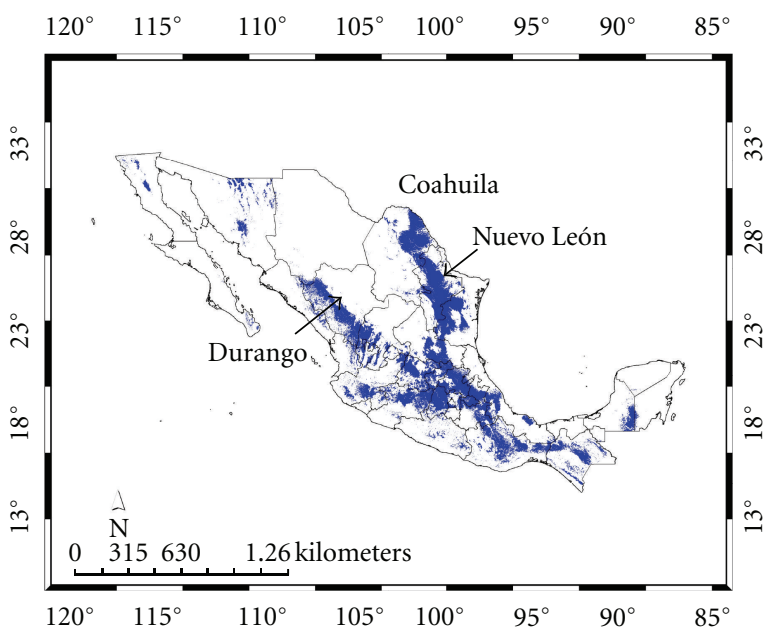

Figure 5: Species distribution model and Mexican states for the Ixodes group. The principal states are shown (see text).

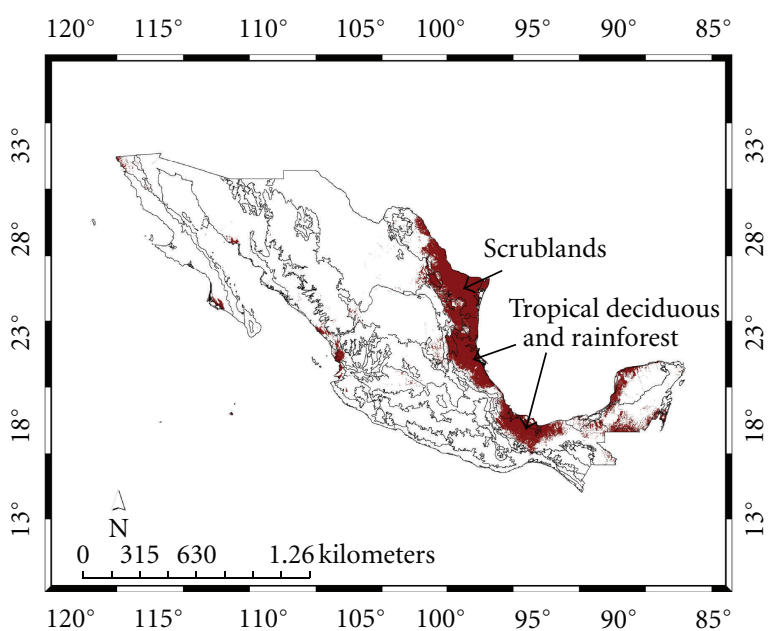

Figure 6: Species distribution model and ecoregions for Amblyomma cajennense. The principal ecoregions are shown (see text).

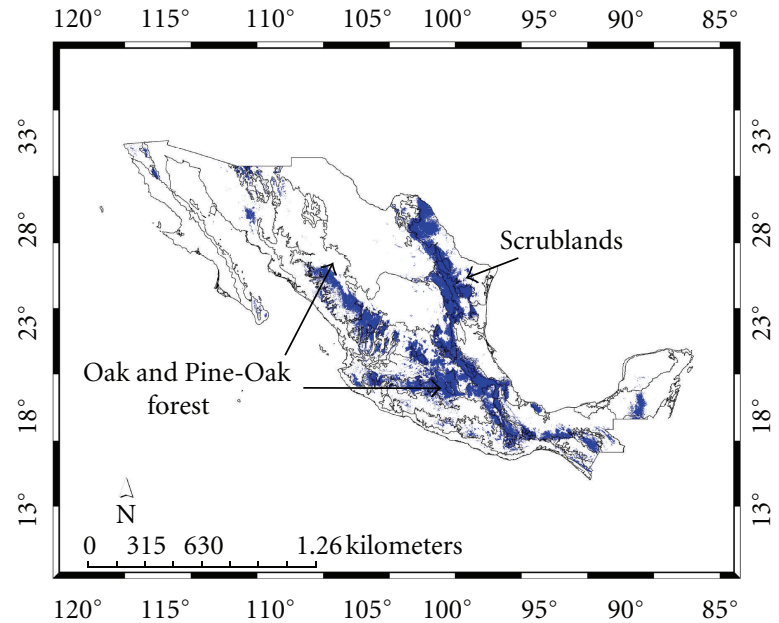

Figure 7: Species distribution model and ecoregions for the Ixodes group. The principal ecoregions are shown (see text).

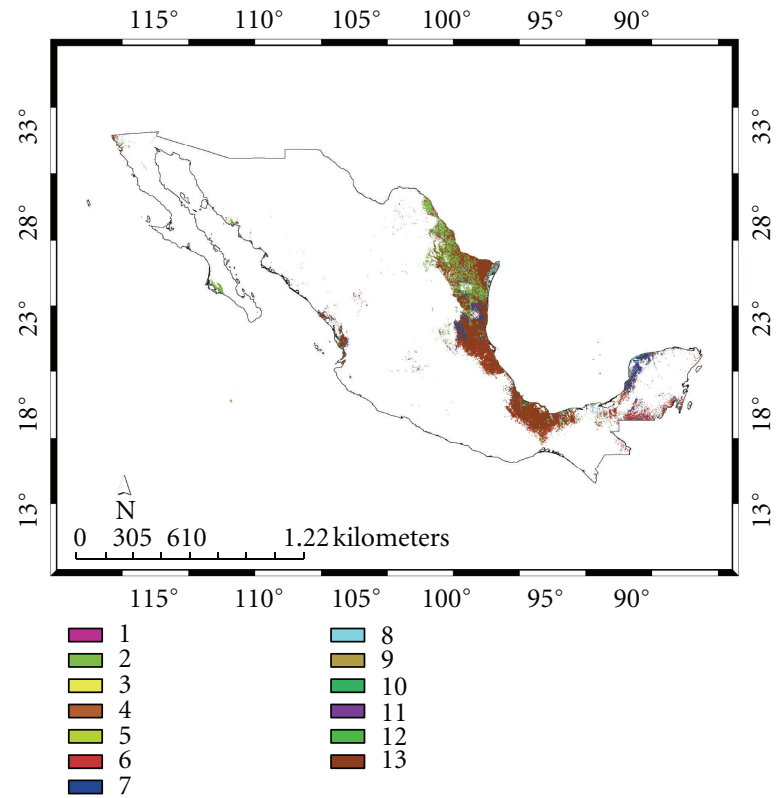

FIGURE 8: Species distribution model and vegetation types for Amblyomma cajennense: (1) grassland; (2) scrubland; (3) pine forest; (4) oak forest; (5) pine-oak forest; (6) tropical rainforest; (7) tropical deciduous forest; (8) aquatic inland vegetation; (9) cloud forest; (10) mangle; (11) palms/palm plantations; (12) savanna; (13) other vegetation types/not known.

were most likely to be infested with $A$. cajennense when the pasture had mixed vegetation (grasses and shrubs) and was cut less than once per year [38]. In Argentina, A. cajennense was more abundant in forested areas than open areas [39]. In contrast, species from the Ixodes group are typically collected in heavily forested or dense brushy areas.

\section{Conclusion}

Species distribution models are potentially a powerful tool for assessing risk from vector-borne diseases [12, 17]. Even 


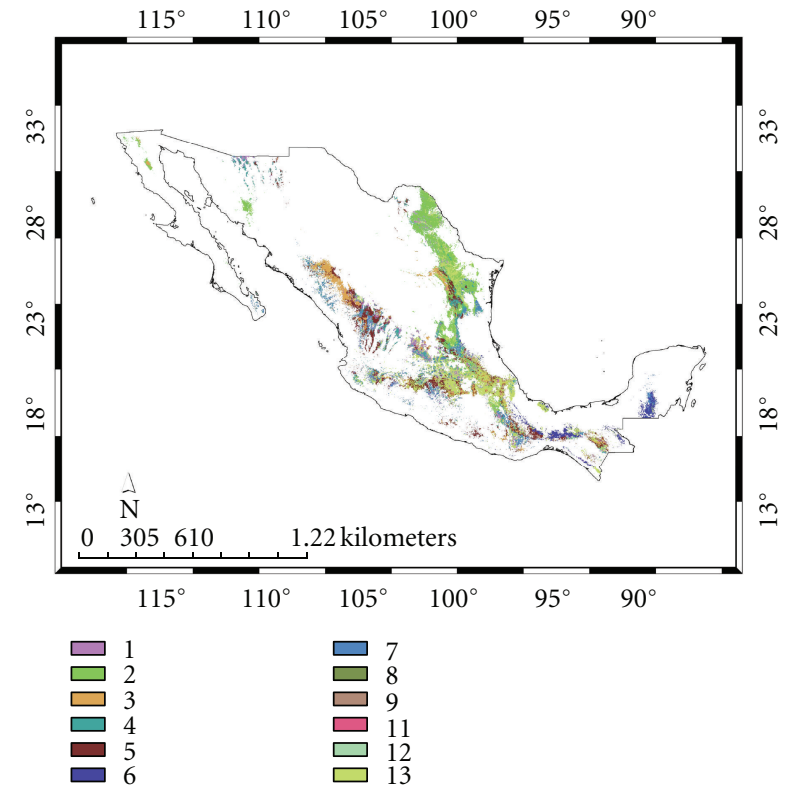

Figure 9: Species distribution model and vegetation types for the Ixodes group: (1) grassland; (2) scrubland; (3) pine forest; (4) oak forest; (5) pine-oak forest; (6) tropical rainforest; (7) tropical deciduous forest; (8) aquatic inland vegetation; (9) cloud forest; (10) mangle; (11) palms/palm plantations; (12) savanna; (13) other vegetation types/not known.

in systems as poorly understood as the one examined here, patterns of concordance in geographic or ecologic space can provide testable hypotheses for host, vector, and reservoir interactions besides their associations with habitat type, vegetation, or ecoregion. Such distributional hypotheses can form the basis for field studies, including analyses of specific parameters of species ecologic niches $[40,41]$, prediction of species distributions across scenarios of climate change $[14,42,43]$, prediction of species invasions $[9,17,44,45]$, assessment of patterns of evolutionary change in ecologic parameters [46], and spatial/epidemiologic stratification of disease endemic areas.

Little is known about Lyme disease and its transmission cycle in Mexico. Assuming that the Ixodes group contains the vectors responsible for transmission, the results presented here identify the geographical regions and ecological characteristics of the regions with the highest potential for transmission: high-altitude low-temperature areas. The SDM also suggests why Lyme disease is relatively rare in the southern United States: the high temperatures of these areas make them relatively less suitable for potential Ixodes vectors.

Should A. cajennense affect the enzootic transmission cycle and assist with maintenance of $B$. burgdorferi in reservoir species, the area of high risk extends into the eastern lowlands of Mexico where the SDM for this species complements that of the Ixodes group. This result suggests that it is important to test $A$. cajennense for vector competence using appropriate laboratory methods.

Field efforts are currently under way to collect specimens of potential mammal reservoirs of $B$. burgdorferi and $R$. rickettsii. SDMs of these species will permit analysis of spatial correlations between them and the vector SDMs which will permit the formulation of testable hypotheses about the Lyme disease cycle in Mexico.

\section{Acknowledgments}

For unpublished tick occurrence data, thanks are due to Kelly Pierce and Chuck Sexton. Thanks are due to Miguel Linaje for discussions. P. Illoldi-Rangel wants to thank the Faculty for the Future program for the grant given for her postdoctoral studies. Finally, thanks are due to the Texas Ecolab program and anonymous landowners for financial assistance and access to property. This project is partially funded by the Universidad Nacional Autónoma de Mexico (PAPIIT IN202711) and the Consejo Nacional de Ciencia y Tecnología (CONACYT SALUD-2008-01-87868).

\section{References}

[1] P. M. Rath, B. Ibershoff, A. Mohnhaupt et al., "Seroprevalence of Lyme borreliosis in forestry workers from Brandenburg, Germany," European Journal of Clinical Microbiology and Infectious Diseases, vol. 15, no. 5, pp. 372-377, 1996.

[2] CDC, "Provisional cases of selected notifiable diseases, United States, weeks ending December 30, 2006," Morbidity and Mortality Weekly Reports, vol. 55, pp. 51-52, 2007.

[3] G. Gordillo, J. Torres, F. Solorzano, R. Cedillo-Rivera, R. TapiaConyer, and O. Muñoz, "Serologic evidences suggesting the presence of Borrelia burgdorferi infection in Mexico," Archives of Medical Research, vol. 30, no. 1, pp. 64-68, 1999.

[4] G. Gordillo-Perez, J. Torres, F. Solorzano-Santos, V. GarduñoBautista, R. Tapia-Conyer, and O. Muñoz, "Seroepidemiologic study of Lyme's borreliosis in Mexico City and the northeast of the Mexican Republic," Salud Pública de México, vol. 45, pp. 351-355, 2003 (Spanish).

[5] G. Gordillo-Pérez, J. Torres, F. Solórzano-Santos et al., "Borrelia burgdorferi infection and cutaneous lyme disease, Mexico," Emerging Infectious Diseases, vol. 13, no. 10, pp. 1556-1558, 2007.

[6] C. E. Souza, J. Moraes-Filho, M. Ogrzewalska et al., "Experimental infection of capybaras Hydrochoerus hydrochaeris by Rickettsia rickettsii and evaluation of the transmission of the infection to ticks Amblyomma cajennense," Veterinary Parasitology, vol. 161, no. 1-2, pp. 116-121, 2009.

[7] M. B. Labruna, "Ecology of rickettsia in South America," Annals of the New York Academy of Sciences, vol. 1166, pp. 156166, 2009.

[8] G. Montiel-Parra, H. Fuentes-Moreno, and M. Vargas, "First record of Ixodes cookei (Acari: Ixodidae) in Mexico," Revista Mexicana de Biodiversidad, vol. 78, no. 1, pp. 205-206, 2007.

[9] C. Guzmán-Cornejo and R. G. Robbins, "The genus Ixodes (Acari: Ixodidae) in Mexico: adult identification keys, diagnoses, hosts, and distribution," Revista Mexicana de Biodiversidad, vol. 81, no. 2, pp. 289-298, 2010.

[10] A. Estrada-Peña, A. A. Guglielmone, and A. J. Mangold, "The distribution and ecological 'preferences' of the tick Amblyomma cajennense (Acari: Ixodidae), an ectoparasite of humans and other mammals in the Americas," Annals of Tropical Medicine and Parasitology, vol. 98, no. 3, pp. 283-292, 2004.

[11] V. Álvarez and M. R. Bonilla, "Adultos y ninfas de la garrapata Amblyomma cajennense Fabricius (Acari: Ixodidae) en 
equinos y bovinos," Agronomía Costarricense, vol. 31, no. 1, pp. 61-69, 2007.

[12] A. T. Peterson, "Biogeography of diseases: a framework for analysis," Naturwissenschaften, vol. 95, no. 6, pp. 483-491, 2008.

[13] A. Moffett, N. Shackelford, and S. Sarkar, "Malaria in Africa: vector species' niche models and relative risk maps," PLoS ONE, vol. 2, no. 9, article e824, 2007.

[14] A. T. Peterson, V. Sánchez-Cordero, C. Ben Beard, and J. M. Ramsey, "Ecologic niche modeling and potential reservoirs for Chagas disease, Mexico," Emerging Infectious Diseases, vol. 8, no. 7, pp. 662-667, 2002.

[15] R. K. Meentemeyer, B. L. Anacker, W. Mark, and D. M. Rizzo, "Early detection of emerging forest disease using dispersal estimation and ecological niche modeling," Ecological Applications, vol. 18, no. 2, pp. 377-390, 2008.

[16] C. González, O. Wang, S. E. Strutz, C. González-Salazar, V. Sánchez-Cordero, and S. Sarkar, "Climate change and risk of leishmaniasis in North America: predictions from ecological niche models of vector and reservoir species," PLoS Neglected Tropical Diseases, vol. 4, no. 1, article e585, 2010.

[17] S. Sarkar, S. E. Strutz, D. M. Frank, C. L. Rivaldi, B. Sissel, and V. Sánchez-Cordero, "Chagas disease risk in Texas," PLoS ONE, vol. 4, no. 10, article e836, 2010.

[18] A. T. Peterson and D. A. Vieglais, "Predicting species invasions using ecological niche modeling: new approaches from bioinformatics attack a pressing problem," BioScience, vol. 51, no. 5, pp. 363-371, 2001.

[19] A. T. Peterson and M. Papeş, "Potential geographic distribution of the Bugun Liocichla Liocichla bugunorum, a poorlyknown species from north-eastern India," Indian Birds, vol. 2, pp. 146-149, 2007.

[20] J. Soberón and A. T. Peterson, "Interpretation of models of ecological niches and species' distributional areas," Biodiversity Informatics, vol. 2, pp. 1-10, 2005.

[21] J. Elith, C. H. Graham, R. P. Anderson et al., "Novel methods improve prediction of species' distributions from occurrence data," Ecography, vol. 29, no. 2, pp. 129-151, 2006.

[22] P. A. Hernandez, C. H. Graham, L. L. Master, and D. L. Albert, "The effect of sample size and species characteristics on performance of different species distribution modeling methods," Ecography, vol. 29, no. 5, pp. 773-785, 2006.

[23] S. J. Phillips, M. Dudík, and R. E. Schapire, "A maximum entropy approach to species distribution modeling," in Proceedings of the 21st Century International Conference on Machine Learning, C. E. Brodley, Ed., pp. 655-662, ACM Press, Banff, Canada, 2004.

[24] S. J. Phillips, R. P. Anderson, and R. E. Schapire, "Maximum entropy modeling of species geographic distributions," Ecological Modelling, vol. 190, no. 3-4, pp. 231-259, 2006.

[25] S. J. Phillips and M. Dudík, "Modeling of species distributions with Maxent: new extensions and a comprehensive evaluation," Ecography, vol. 31, no. 2, pp. 161-175, 2008.

[26] C. R. Margules and S. Sarkar, Systematic Conservation Planning, Cambridge University Press, Cambridge, UK, 2007.

[27] J. S. Thorn, V. Nijman, D. Smith, and K. A. I. Nekaris, "Ecological niche modelling as a technique for assessing threats and setting conservation priorities for Asian slow lorises (Primates: Nycticebus)," Diversity and Distributions, vol. 15, no. 2, pp. 289-298, 2009.

[28] L. Ochoa-Ochoa, J. N. Urbina-Cardona, L. B. Vázquez, O. Flores-Villela, and J. Bezaury-Creel, "The effects of gov- ernmental protected areas and social initiatives for land protection on the conservation of Mexican amphibians," PLoS ONE, vol. 4, no. 9, article e6878, 2009.

[29] P. C. Williamson, P. M. Billingsley, G. J. Teltow, J. P. Seals, M. A. Turnbough, and S. F. Atkinson, "Borrelia, Ehrlichia, and Rickettsia spp. in ticks removed from Persons, Texas, USA," Emerging Infectious Diseases, vol. 16, no. 3, pp. 441-446, 2010.

[30] S. J. Dergousoff, A. J. A. Gajadhar, and N. B. Chilton, "Prevalence of Rickettsia in Canadian populations of the ticks Dermacentor andersoni and D. variabilis," Applied and Environmental Microbiology, vol. 75, pp. 1786-1789, 2009.

[31] A. Moffett, S. Strutz, N. Guda et al., "A global public database of disease vector and reservoir distributions," PLoS Neglected Tropical Diseases, vol. 3, no. 3, article e378, 2009.

[32] R. J. Hijmans, D. M. Spooner, A. R. Salas, L. Guarino, and J. de la Cruz, Atlas of Wild Potatoes. Systematic and Ecogeographic Studies on Crop Genepools, vol. 10, International Plant Genetic Resources Institute, Rome, Italy, 2002.

[33] S. Solís, El efecto del Programa de Control de Boophilus microplus en la Dinámica de Población de Amblyomma spp. en México. Actas de la Consulta de Expertos Sobre la Erradicación de las Garrapatas con Referencia Especial a las Américas, Food and Agriculture Organization, México, Mexico, 1987.

[34] Anónimo, Estudio Ecológico y Epidemiológico de Garrapatas en Guatemala, Instituto Interamericano de Cooperación con la Agricultura-Ministerio de Agricultura, Ganadería y Alimentación, Guatemala, Mexico, 1988.

[35] C. Víctor Álvarez, M. Roberto Bonilla, and G. Idania Chacón, "Distribución de la garrapata Amblyomma cajennense (Acari: Ixodidae) sobre Bos taurus y Bos indicus en Costa Rica," Revista de Biologia Tropical, vol. 48, no. 1, pp. 129-135, 2000.

[36] A. Estrada-Peña, "Prediction of habitat suitability for ticks," Annals of the New York Academy of Sciences, vol. 1078, pp. 275284, 2006

[37] M. W. Smith, "Some aspects of the ecology and lifecycle of Amblyomma cajennense (Fabricius 1787) in Trinidad and their influence on tick control measures," Annals of Tropical Medicine and Parasitology, vol. 69, no. 1, pp. 121-129, 1975.

[38] M. B. Labruna, C. E. Kerber, F. Ferreira, J. L. H. Faccini, D. T. De Waal, and S. M. Gennari, "Risk factors to tick infestations and their occurrence on horses in the state of São Paulo, Brazil," Veterinary Parasitology, vol. 97, no. 1, pp. 1-14, 2001.

[39] A. A. Guglielmone, A. J. Mangold, D. H. Aguirre, and A. B. Gaido, "Ecological aspects of four species of ticks found on cattle in Salta, Northwest Argentina," Veterinary Parasitology, vol. 35, no. 1-2, pp. 93-101, 1990.

[40] A. T. Peterson, "Predicting species' geographic distributions based on ecological niche modeling," Condor, vol. 103, no. 3, pp. 599-605, 2001.

[41] V. Sánchez-Cordero, P. Illoldi-Rangel, M. Linaje, S. Sarkar, and A. T. Peterson, "Deforestation and extant distributions of Mexican endemic mammals," Biological Conservation, vol. 126, no. 4, pp. 465-473, 2005.

[42] A. T. Peterson, V. Sánchez-Cordero, J. Soberón, J. Bartley, R. W. Buddemeier, and A. G. Navarro-Sigüenza, "Effects of global climate change on geographic distributions of Mexican Cracidae," Ecological Modelling, vol. 144, no. 1, pp. 21-30, 2001.

[43] V. Sánchez-Cordero, P. Illoldi-Rangel, T. Escalante et al., "Deforestation and biodiversity conservation in México," in Endangered Species: New Research, A. Columbus and L. Kuznetsov, Eds., Nova Science, 2009.

[44] A. T. Peterson, J. T. Bauer, and J. N. Mills, "Ecologic and geographic distribution of filovirus disease," Emerging Infectious Diseases, vol. 10, no. 1, pp. 40-47, 2004. 
[45] R. S. Levine, A. T. Peterson, K. L. Yorita, D. Carroll, I. K. Damon, and M. G. Reynolds, "Ecological niche and geographic distribution of human monkeypox in Africa," PLoS ONE, vol. 2, no. 1, article e176, 2007.

[46] A. T. Peterson and K. P. Cohoon, "Sensitivity of distributional prediction algorithms to geographic data completeness," Ecological Modelling, vol. 117, no. 1, pp. 159-164, 1999. 


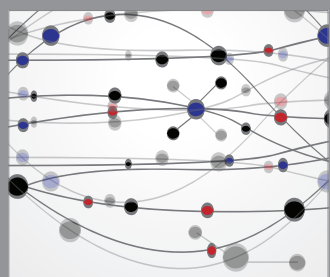

The Scientific World Journal
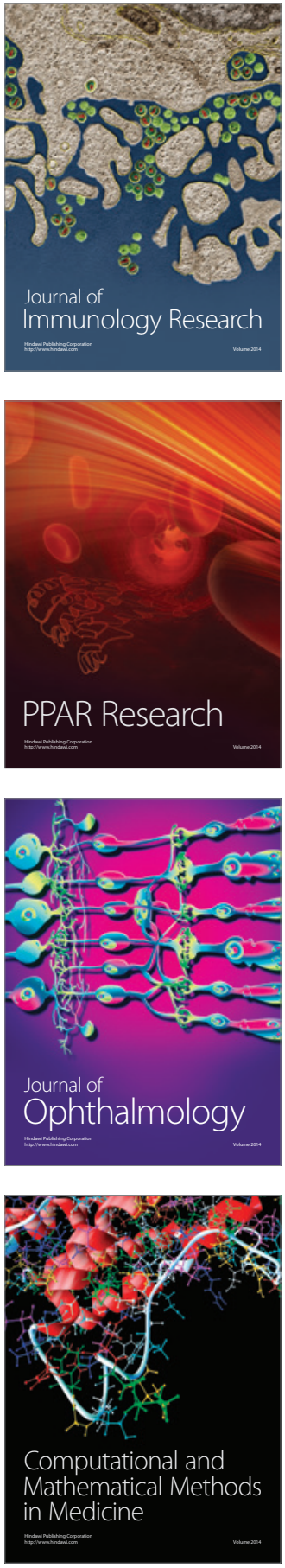

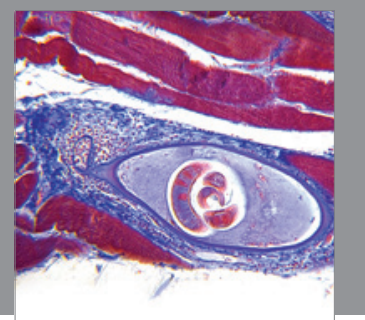

Gastroenterology

Research and Practice
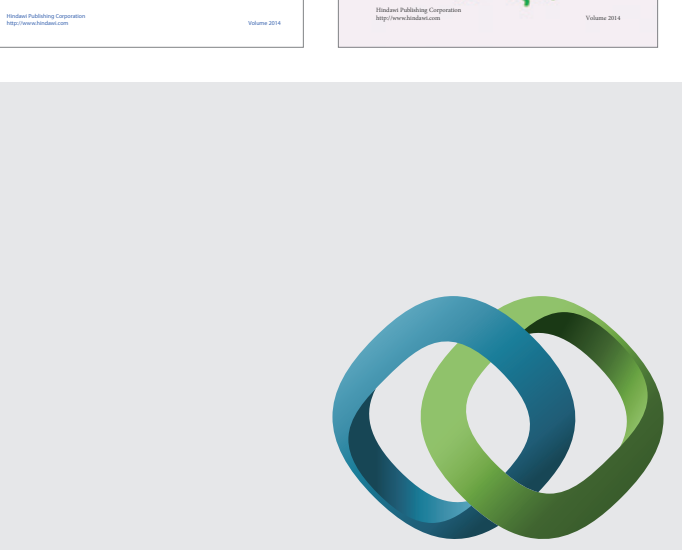

\section{Hindawi}

Submit your manuscripts at

http://www.hindawi.com
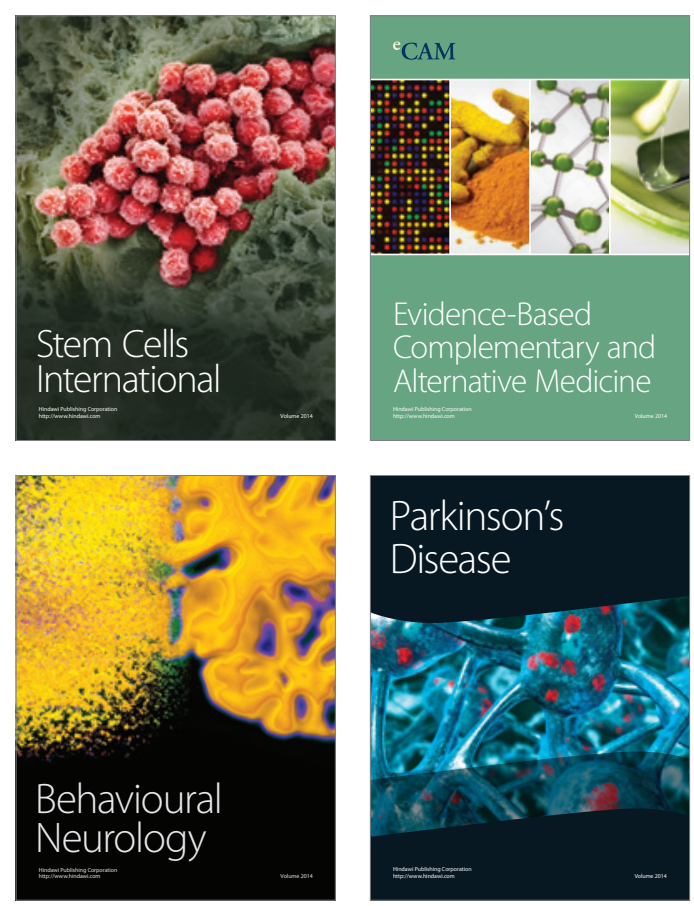

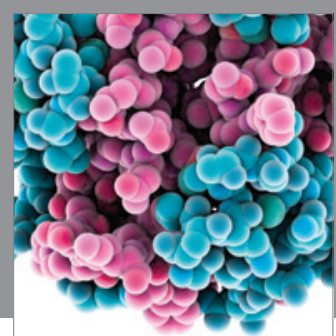

Journal of
Diabetes Research

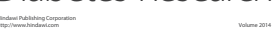

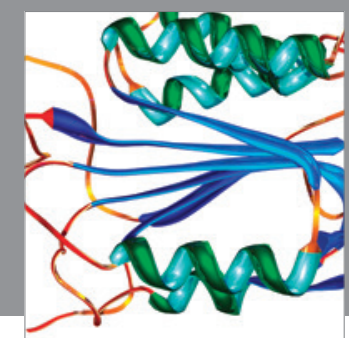

Disease Markers
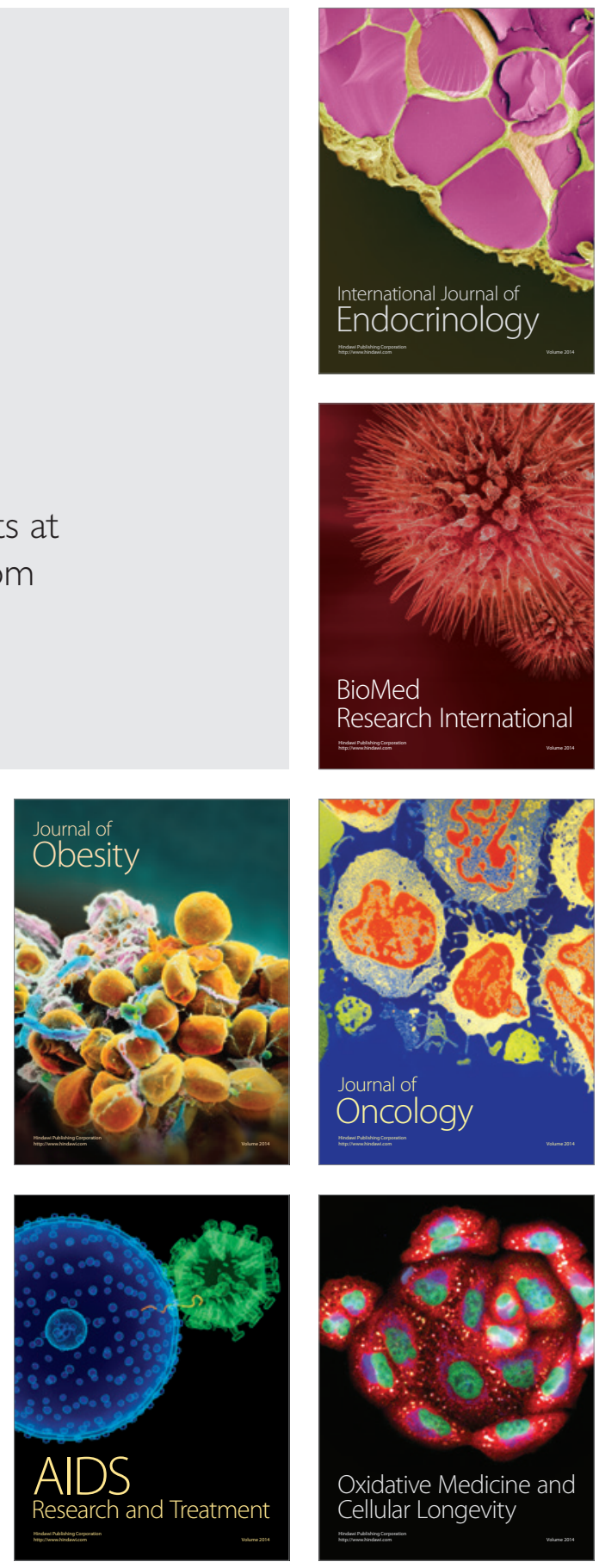